\title{
Molecular mechanisms triggered by low-calcium diets
}

\author{
Viviana Centeno, Gabriela Díaz de Barboza, Ana Marchionatti, Valeria Rodríguez and Nori Tolosa de Talamoni* \\ Laboratorio de Metabolismo Fosfocálcico y Vitamina D 'Dr. F. Cañas', Cátedra de Bioquímica y Biología Molecular, Facultad \\ de Ciencias Médicas, Universidad Nacional de Córdoba, Córdoba, Argentina
}

\begin{abstract}
$\mathrm{Ca}$ is not only essential for bone mineralisation, but also for regulation of extracellular and intracellular processes. When the $\mathrm{Ca}^{2+}$ intake is low, the efficiency of intestinal $\mathrm{Ca}^{2+}$ absorption and renal $\mathrm{Ca}^{2+}$ reabsorption is increased. This adaptive mechanism involves calcitriol enhancement via parathyroid hormone stimulation. Bone is also highly affected. Low $\mathrm{Ca}^{2+}$ intake is considered a risk factor for osteoporosis. Patients with renal lithiasis may be at higher risk of recurrence of stone formation when they have low $\mathrm{Ca}^{2+}$ intake. The role of dietary $\mathrm{Ca}^{2+}$ on the regulation of lipid metabolism and lipogenic genes in adipocytes might explain an inverse relationship between dairy intake and BMI. Dietary $\mathrm{Ca}^{2+}$ restriction produces impairment of the adipocyte apoptosis and dysregulation of glucocorticosteroid metabolism in the adipose tissue. An inverse relationship between hypertension and a low- $\mathrm{Ca}^{2+}$ diet has been described. $\mathrm{Ca}^{2+}$ facilitates weight loss and stimulates insulin sensitivity, which contributes to the decrease in the blood pressure. There is also evidence that dietary $\mathrm{Ca}^{2+}$ is associated with colorectal cancer. Dietary $\mathrm{Ca}^{2+}$ could alter the ratio of faecal bile acids, reducing the cytotoxicity of faecal water, or it could activate $\mathrm{Ca}^{2+}$-sensing receptors, triggering intracellular signalling pathways. Also it could bind luminal antigens, transporting them into mucosal mononuclear cells as a mechanism of immunosurveillance and promotion of tolerance. Data relative to nutritional $\mathrm{Ca}^{2+}$ and incidences of other human cancers are controversial. Health professionals should be aware of these nutritional complications and reinforce the dairy intakes to ensure the recommended $\mathrm{Ca}^{2+}$ requirements and prevent diseases.
\end{abstract}

\section{Low-Ca ${ }^{2+}$ diet: Intestine: Kidney: Bone: Hypertension: Lipids: Cancer}

\section{Introduction}

$\mathrm{Ca}$ is a fundamental building block of bone and, hence, is essential for achieving optimal peak bone mass in the first two to three decades of life and for the maintenance of bone mass, later in life ${ }^{(1)}$. It is also important for many physiological processes such as nerve impulse transmission, muscle contraction, blood coagulation, secretory activity and apoptosis ${ }^{(2,3)}$. The dysregulation of $\mathrm{Ca}$ homeostasis appears to be a common factor linking conditions such as hypertension, insulin resistance and obesity ${ }^{(4)}$. Although some epidemiological studies have shown an inverse association between dietary $\mathrm{Ca}^{2+}$ and risk of breast and colon cancer, in prostate cancer, a high $\mathrm{Ca}^{2+}$ intake has been associated with higher $\operatorname{risk}^{(5-8)}$. As the diet is the only external source of $\mathrm{Ca}^{2+}$, appropriate levels of the mineral intake according to age and sex are recommended, in order to preserve bone health and metabolic balance. These requirements are higher in childhood, pregnancy and lactation. The intake of dairy products and $\mathrm{Ca}^{2+}$ supplements has been highly advertised for many years. However, most of the studies show that $\mathrm{Ca}^{2+}$ intake is much lower than the international recommendations in the majority of countries ${ }^{(9-11)}$, with a few exceptions such as Finland and Denmark ${ }^{(12,13)}$. Although adaptive mechanisms have evolved to control the amount of $\mathrm{Ca}^{2+}$ that is absorbed, the efficiency of this response involves metabolic changes, whose persistence with time may be deleterious.

\section{Effect of dietary $\mathrm{Ca}^{2+}$ deficiency on $\mathrm{Ca}^{2+}$ homeostasis and the metabolism of calciotropic hormones}

Dietary $\mathrm{Ca}^{2+}$ deficiency provokes increments in the efficiency of intestinal $\mathrm{Ca}^{2+}$ absorption and in renal $\mathrm{Ca}^{2+}$

Abbreviations: BMD, bone mineral density; CaR, Ca-sensing receptor; CYP24, 24-hydroxylase; CYP27B1, 25-OH-cholecalciferol 1-hydroxylase; DASH, Dietary Approaches to Stop Hypertension; IGF-1, insulin-like growth factor-1; KO, knock-out; $1,25(\mathrm{OH})_{2} \mathrm{D}_{3}$, 1,25-dihydroxyvitamin $\mathrm{D}_{3} ; 25 \mathrm{OHD}_{3}, 25$-hydroxyvitamin $\mathrm{D}_{3}$; PTH, parathyroid hormone; TRPV6, transient receptor potential cation channel, subfamily V, member 6; VDR, vitamin D receptor.

* Corresponding author: Dr Nori Tolosa de Talamoni, fax + 54351 4333072, email ntolosa@biomed.uncor.edu 
reabsorption ${ }^{(14)}$. This is an adaptation process performed as a compensation mechanism in order to cover the cation needs of the organism ${ }^{(15)}$. Serum $\mathrm{Ca}^{2+}$ levels may be normal or low, according to the extent and degree of $\mathrm{Ca}^{2+}$ deficiency. We have demonstrated hypocalcaemia in chicks after $10 \mathrm{~d}$ of low $\mathrm{Ca}^{2+}$ intake $(0 \cdot 1 \%)^{(16,17)}$. The mechanisms of adaptation to low- $\mathrm{Ca}^{2+}$ diets depend on the vitamin $\mathrm{D}$ status, mainly of the rate of 1,25-dihydroxyvitamin $\mathrm{D}_{3}$ $\left(1,25(\mathrm{OH})_{2} \mathrm{D}_{3}\right)$ synthesis. Cholecalciferol is hydroxylated in two steps: the first hydroxylation occurs at the carbon at the 25 position in the liver, and the second hydroxylation takes place in the kidney at the level of the carbon at the 1 position $^{(18)}$. An increase in the serum levels of $1,25(\mathrm{OH})_{2} \mathrm{D}_{3}$ by a low-Ca ${ }^{2+}$ diet has been shown in human subjects ${ }^{(19)}$, chicks ${ }^{(20)}$, ewes ${ }^{(21)}$ and rats ${ }^{(22)}$, but not in hamsters ${ }^{(23)}$. On the contrary, dietary $\mathrm{Ca}^{2+}$ restriction in the presence of constant vitamin D intake may cause depletion of 25-hydroxycholecalciferol, as shown in the plasma of rats as a consequence of high activity of the renal enzyme 25$\mathrm{OH}-$ cholecalciferol 1-hydroxylase (CYP27B1), which catalyses the transformation of 25-hydroxyvitamin $\mathrm{D}_{3}$ $\left(25 \mathrm{OHD}_{3}\right)$ into $1,25(\mathrm{OH})_{2} \mathrm{D}_{3}^{(24)}$. In renal stone formers, identified as absorptive hypercalciuric or renal hypercalciuric, Gascon-Barré et al. ${ }^{(25)}$ have observed lower circulating levels of $25 \mathrm{OHD}_{3}$ when they were on a low-Ca ${ }^{2+}$ diet as compared with those values shown with a normal$\mathrm{Ca}^{2+}$ diet. CYP27B1 mRNA has been found to be expressed in the duodenum, the site of maximal vitamin D-regulated intestinal $\mathrm{Ca}^{2+}$ absorption ${ }^{(26)}$, but at low levels relative to the kidney. Besides, it has been demonstrated that the intestinal enzyme is not altered by dietary $\mathrm{Ca}^{2+}$ restriction, which is the classical condition regulating the renal CYP27B1 $1^{(26)}$. High levels of $1,25(\mathrm{OH})_{2} \mathrm{D}_{3}$, caused by low- $\mathrm{Ca}^{2+}$ diets, modulate the adaptive changes in intestinal $\mathrm{Ca}^{2+}$ absorption and in renal $\mathrm{Ca}^{2+}$ reabsorption, apparently through vitamin D-mediated transcriptional activation ${ }^{(27)}$. An increment in the expression of proteins presumably involved in the $\mathrm{Ca}^{2+}$ movement through the cells has been reported, such as the $\mathrm{Ca}^{2+}$ channels $\mathrm{Ca}$ transport protein 1 (transient receptor potential cation channel, subfamily $\mathrm{V}$, member 6; TRPV6) and Ca transport protein 2 (transient receptor potential cation channel, subfamily $\mathrm{V}$, member 5; TRPV5) ${ }^{(28)}$, calbindin $\mathrm{D}_{9 \mathrm{k}}$, calbindin $\mathrm{D}_{28 \mathrm{k}}^{(29)}, \mathrm{Ca}^{2+}$-ATPase or the $\mathrm{Ca}^{2+}$ pump ${ }^{(29)}$ and the $\mathrm{Na}^{+} / \mathrm{Ca}^{2+}$ exchanger ${ }^{(17)}$.

The effect of low- $\mathrm{Ca}^{2+}$ diets on other metabolites derived from vitamin D is not well established. Fox et al. ${ }^{(30)} \mathrm{did}$ not show an increase in $1,25(\mathrm{OH})_{2} \mathrm{D}_{3}$ catabolism, but they showed enhancement of the renal clearance of $1,25(\mathrm{OH})_{2} \mathrm{D}_{3}$. Goff et al. ${ }^{(31)}$ found a 6- to 20 -fold increase in 24-hydroxylase (CYP24) activity in animals exposed to $\mathrm{Ca}^{2+}$-restricted diets as compared with those fed a $\mathrm{Ca}^{2+}$ replete diet.

Parathyroid hormone (PTH) secretion is also stimulated by low- $\mathrm{Ca}^{2+} \operatorname{diets}^{(32)}$. Several studies have shown that the Ca-sensing receptor $(\mathrm{CaR})$ of parathyroid cells is a key mediator of direct actions of extracellular $\mathrm{Ca}^{2+}$ on PTH secretion. $\mathrm{CaR}$ is a $\mathrm{G}$ protein-coupled receptor, whose activation by extracellular $\mathrm{Ca}^{2+}$ results in the suppression of PTH release $\mathrm{e}^{(33,34)}$. CaR was first identified in bovine parathyroid cells, and successively found in neurons, osteoblasts, keratinocytes, enterocytes and mammary epithelial cells. The sensitivity of parathyroid glands to small changes in serum $\mathrm{Ca}$ is remarkable. When hypocalcaemia is acute, the glands secrete PTH in a few seconds or minutes, this release being maintained between 60 and $90 \mathrm{~min}$. A reduction in the intracellular PTH degradation also contributes to sustain this response. If hypocalcaemia is maintained for several hours or days, PTH gene expression is increased and if the same condition persists for several days or weeks, cellular proliferation in the glands is augmented ${ }^{(35)}$. In rabbits, it has been found that 6 weeks of a low- $\mathrm{Ca}^{2+}$ diet produce parathyroid hyperplasia, characterised by increases in PTH secretion, glandular weight and proliferation and by a decrease in $\mathrm{CaR}$ mRNA $^{(36)}$. Brown ${ }^{(37)}$ defined the set-point of the PTH secretion: $\mathrm{Ca}^{2+}$ levels ratio, which is the $\mathrm{Ca}$ concentration producing half of the maximal inhibition of secretion. This relationship has been useful in the analysis of PTH from patients with secondary hyperparathyroidism due to renal failure and in other conditions. Secondary hyperparathyroidism as well as dietary $\mathrm{Ca}^{2+}$ deprivation are characterised by an increase in parathyroid epithelial cell number. By using rats fed a low- $\mathrm{Ca}^{2+}$ diet for 8 weeks, it has been shown that endothelin-1 is significantly increased and bosentan, an endothelin-1 receptor antagonist, prevents any increase in the proliferation of parathyroid cells. Therefore, the blockage of endothelin receptors has been suggested to be an important strategy for preventing secondary hyperparathyroidism $^{(38)}$. Miao et al. ${ }^{(39)}$ have observed in PTHdeficient mice placed on a low- $\mathrm{Ca}^{2+}$ diet that renal CYP27B1 expression increases despite the absence of PTH, leading to an increase in serum $1,25(\mathrm{OH})_{2} \mathrm{D}_{3}$ levels, osteoclastogenesis, and a profound bone resorption. The authors think that although PTH is the first defence against hypocalcaemia, $1,25(\mathrm{OH})_{2} \mathrm{D}_{3}$ can be mobilised in the absence of PTH, to protect against an intense $\mathrm{Ca}^{2+}$ deficiency. Recently, it has been suggested that oestrogen is also necessary for the full adaptive response to a low- $\mathrm{Ca}^{2+}$ diet mediated by both PTH and $1,25(\mathrm{OH})_{2} \mathrm{D}_{3}^{(40)}$.

Regarding calcitonin, another important calciotropic hormone, it has been shown that diets deficient in $\mathrm{Ca}^{2+}$ and vitamin $\mathrm{D}$ fed to weanling rats for 3 weeks do not change calcitonin mRNA levels, in contrast to the large increases in PTH mRNA levels. So, the authors conclude that calcitonin gene expression in vivo in the rat is not affected by changes in serum $\mathrm{Ca}^{2+(41)}$. The lack of studies on this issue makes it difficult to have a precise idea about the effect of $\mathrm{Ca}^{2+}$ deficiency on this hormone and its action.

\section{Alteration of the intestinal function}

Dietary $\mathrm{Ca}^{2+}$ deficiency exerts an important impact on the intestine and its function, mainly affecting the composition of intestinal plasma membranes and $\mathrm{Ca}^{2+}$ transport. Intestinal $\mathrm{Ca}^{2+}$ absorption seems to occur by two different mechanisms: transcellular and paracellular pathways. Both mechanisms are regulated by hormones, nutrients and other factors, which have been studied for many years due to their close relationship with osteoporosis and other disorders related to $\mathrm{Ca}^{2+}$ metabolism ${ }^{(15)}$. The transcellular pathway comprises three steps: entry across the brush-border membrane, intracellular diffusion and exit through the 
basolateral membrane. As mentioned above, all the genes presumably involved in the transcellular pathway are enhanced by a low- $\mathrm{Ca}^{2+}$ diet, probably by activation of the vitamin D endocrine system ${ }^{(16,17,27,28)}$. Furthermore, the enhancement in the activity and expression of the intestinal $\mathrm{Ca}^{2+}$ pump and the $\mathrm{Na}^{+} / \mathrm{Ca}^{2+}$ exchanger caused by $\mathrm{Ca}^{2+}$ deficient diets occurs either in mature or in undifferentiated enterocytes $^{(17)}$. However, vitamin D receptor (VDR) levels are decreased by low-Ca ${ }^{2+}$ diets. Ferrari et al. ${ }^{(42)}$ suggested that dietary $\mathrm{Ca}^{2+}$ deficiency might have a dual effect on VDR gene expression because homologous stimulation of VDR gene expression by calcitriol does not occur on a low$\mathrm{Ca}^{2+}$ diet, as a result of a transcriptional suppression by a concomitant increase of PTH. In our laboratory, we found down-regulation of VDR expression by a low-Ca ${ }^{2+}$ diet, an effect that was independent of the degree of cell maturation $^{(17)}$. We think that high levels of serum $1,25(\mathrm{OH})_{2} \mathrm{D}_{3}$ caused by low-Ca ${ }^{2+}$ diets do not regulate the intestinal function by up-modulation of its nuclear receptor but promoting differentiation, which would produce cells more capable of expressing vitamin Ddependent genes required for $\mathrm{Ca}^{2+}$ absorption.

Other biochemical changes produced by low- $\mathrm{Ca}^{2+}$ diets in the intestine are related to the protein sulfhydryl groups and the lipid composition and fluidity of intestinal membranes. We have shown that the reactivity and availability of sulfhydryl groups from intestinal brushborder membrane proteins of chicks are increased by low- $\mathrm{Ca}^{2+} \operatorname{diets}^{(43)}$. Although the functional significance of this response remains unknown, it is quite possible that the sulfhydryl status of the brush-border membrane proteins might be involved in the vitamin D-dependent intestinal $\mathrm{Ca}^{2+}$ absorption, as indicated by Mykkanen \& Wasserman $^{(44)}$. With regard to the lipid composition, we have shown minor changes in the fatty acid content of the intestinal basolateral membrane; however, lipid fluidity of diphenylhexatriene-labelled intestinal basolateral membrane from chicks is highly increased by the dietary $\mathrm{Ca}^{2+}$ restriction as compared with that from the control group ${ }^{(16)}$ Thus, it appears that the $\mathrm{Ca}^{2+}$ exit through the basolateral membrane from the enterocytes in chicks adapted to a low$\mathrm{Ca}^{2+}$ diet is greater than that from the control group; higher expression and activity of the $\mathrm{Ca}^{2+}$ pump and the $\mathrm{Na}^{+} / \mathrm{Ca}^{2+}$ exchanger and changes in lipid composition and fluidity, which could affect the microdomains of ion transporters, would be the mechanisms responsible for these adaptive responses of the intestine ${ }^{(18)}$. The activity of alkaline phosphatase, another candidate molecule to be involved in intestinal $\mathrm{Ca}^{2+}$ absorption, is highly increased in chicks by dietary $\mathrm{Ca}^{2+}$ restriction, either in mature or immature enterocytes $^{(17)}$. This could be a concomitant effect of higher levels of $1,25(\mathrm{OH})_{2} \mathrm{D}_{3}$ triggered by a low- $\mathrm{Ca}^{2+}$ diet, but a real role in intestinal $\mathrm{Ca}^{2+}$ absorption cannot be discarded.

Recent data showed that under low dietary $\mathrm{Ca}^{2+}$ conditions there was a 4.1-, 2.9- and 3.9-fold increase in $\mathrm{Ca}^{2+}$ transport in the duodenum of wild-type, TRPV6 knock-out $(\mathrm{KO})$ and calbindin $\mathrm{D}_{9 \mathrm{k}} \mathrm{KO}$ mice, respectively. In the TRPV6/calbindin $\mathrm{D}_{9 \mathrm{k}}$ double $\mathrm{KO}$ mice fed a low-Ca ${ }^{2+}$ diet there was a $2 \cdot 1$-fold increase in the duodenal $\mathrm{Ca}^{2+}$ transport. Therefore, this study shows that active intestinal $\mathrm{Ca}^{2+}$ transport occurs in the absence of TRPV6 and calbindin $\mathrm{D}_{9 \mathrm{k}}$, which challenges the dogma that both proteins are essential for vitamin D-induced active intestinal $\mathrm{Ca}^{2+}$ transport $^{(45)}$. The data would indicate that TRPV6 may not be the rate-limiting factor in the transcellular pathway or its function is partially compensated by an unknown factor. On the basis that insulin-like growth factor-1 (IGF-1) mRNA was significantly induced in the duodenum of double $\mathrm{KO}$ mice under low dietary $\mathrm{Ca}^{2+}$ conditions, it is possible to think that IGF-1 may be the factor that contributes to the increment in intestinal $\mathrm{Ca}^{2+}$ absorption.

Figure 1 shows a schematic representation of mechanisms triggered by dietary $\mathrm{Ca}^{2+}$ restriction on the intestine as has been described above.

\section{Low- $\mathrm{Ca}^{2+}$ diets and bone}

Bone is highly affected by nutritional $\mathrm{Ca}^{2+}$ deficiencies in different periods of life and under some physiological conditions or pharmacological treatments. Kalkwarf et al. ${ }^{(46)}$ have demonstrated that women with low $\mathrm{Ca}^{2+}$ intakes during childhood and adolescence have less bone mass later in life and a greater risk of fractures. Regarding puberty in experimental animals, bone accretion seems to be very influenced by $\mathrm{Ca}^{2+}$ deficiencies. Kasukawa et al. ${ }^{(47)}$ have shown during 2 weeks of pubertal growth that wildtype mice increase femur bone mineral density (BMD) 35 and $7 \%$ when fed normal- or low- $\mathrm{Ca}^{2+}$ diets, respectively, which indicates that bone accretion is impaired during $\mathrm{Ca}^{2+}$ deficiency. Furthermore, these effects were exaggerated in IGF-1 KO mice. $\mathrm{Ca}^{2+}$ deficiency produced decreases in endosteal bone formation parameters and much greater enhancement in the resorbing surface of the endosteum and periosteum of the tibia from the IGF-1 KO mice as compared with the wild-type mice. Although the molecular mechanisms by which IGF-1 deficiency increases serum PTH levels are unknown, these alterations could partially explain the negative impact of the lack of IGF-1 on bone accretion. The anabolic effect of PTH is also altered by nutritional $\mathrm{Ca}^{2+}$ deficiency. Steiner et al. ${ }^{(48)}$ have demonstrated that the anabolic effect of human PTH (1-38) in animal bone is blunted by a low- $\mathrm{Ca}^{2+}$ diet, which suggests that dietary $\mathrm{Ca}^{2+}$ intake is critical during PTH treatment. It has also been demonstrated in experimental animals that accelerated bone resorption, caused by low- $\mathrm{Ca}^{2+}$ diets, promotes the growth of breast cancer tumours implanted in bone, independently of PTH action ${ }^{(49)}$. High vitamin $\mathrm{D}_{3}$ intake does not prevent bone loss induced by dietary $\mathrm{Ca}^{2+}$ restriction, at least in growing rats and mice ${ }^{(26)}$.

Lactation produces a transient loss of bone to provide adequate $\mathrm{Ca}^{2+}$ for milk production. A complete recovery of bone density in the post-weaning period occurs in adult mothers irrespective of dietary $\mathrm{Ca}^{2+}$ levels. However, adolescent mothers with low- $\mathrm{Ca}^{2+}$ diets recover bone loss, but the rate of bone accretion seems not to be sufficient to attain peak bone mass at maturity ${ }^{(50)}$. Furthermore, the Apa I, Bsm I and Taq I VDR gene polymorphisms are associated with bone mass and/or breast milk $\mathrm{Ca}^{2+}$ in lactating adolescents with low $\mathrm{Ca}^{2+}$ intakes. Those adolescent mothers carrying the genotypes $a a$ and $t t$ had a better bone status and those with the genotype $b b$ had higher breast milk $\mathrm{Ca}^{2+(51)}$. 


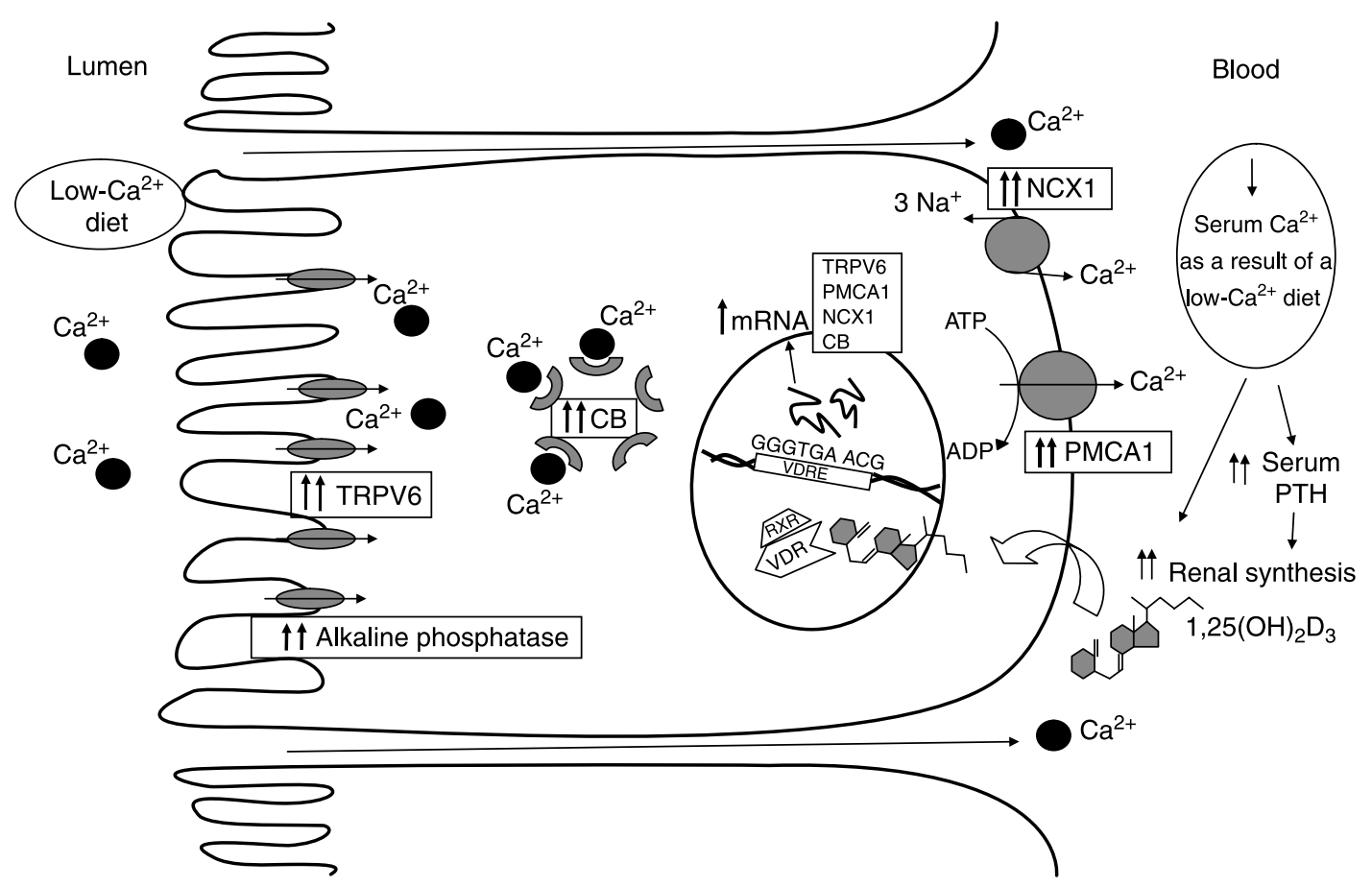

Fig. 1. A diet poor in $\mathrm{Ca}^{2+}$ decreases serum $\mathrm{Ca}^{2+}$ levels, which can be accompanied by normal or low serum phosphate. Hypocalcaemia induces a high parathyroid hormone (PTH) secretion, which in turn promotes renal 1,25-dihydroxyvitamin $\mathrm{D}_{3}\left(1,25(\mathrm{OH})_{2} \mathrm{D}_{3}\right)$ synthesis. This hormone binds to vitamin $D$ receptors (VDR) in the intestine triggering transient receptor potential cation channel, subfamily V, member 6 (TRPV6), calbindin D (CB), $\mathrm{Ca}^{2+}$ pump (PMCA1), $\mathrm{Na}^{+} / \mathrm{Ca}^{2+}$ exchanger (NCX1) and alkaline phosphatase synthesis. As a consequence, the efficiency of intestinal Ca absorption is enhanced. VDRE, vitamin $\mathrm{D}$ response element; RXR, retinoid $\mathrm{X}$ receptor.

Adequate $\mathrm{Ca}^{2+}$ intake has been demonstrated to reduce bone loss in peri- and postmenopausal women and to reduce fractures in women older than 60 years of age. Due to the fact that there is no accurate test to determine $\mathrm{Ca}^{2+}$ deficiency, it is considered that women must meet the recommended $\mathrm{Ca}^{2+}$ intake levels ${ }^{(52)}$. Although a low-Ca ${ }^{2+}$ diet has been considered as a risk factor for developing osteoporosis, a recent article reviewing several databases for low BMD or for bone loss in healthy men aged 50 years or older has found that dietary $\mathrm{Ca}^{2+}$ is a weak risk factor for low $\mathrm{BMD}^{(53)}$. The interaction of dietary $\mathrm{Ca}^{2+}$ content and physical activity seems to be very important to determine adequate BMD. It has been found in Scottish women with low or medium $\mathrm{Ca}^{2+}$ intake that BMD was higher amongst the most active individuals ${ }^{(54)}$.

\section{Alteration of the renal function}

It is well known that low blood $\mathrm{Ca}^{2+}$ increases PTH levels, which act on the kidneys increasing $\mathrm{Ca}^{2+}$ reabsorption and $1,25(\mathrm{OH})_{2} \mathrm{D}_{3}$ production through the activation of CYP27B 1 $1^{(55)}$. Overproduction of $1,25(\mathrm{OH})_{2} \mathrm{D}_{3}$ in the kidneys is regulated by CYP24, which inactivates calcitriol by hydroxylation of the side chain at the carbon at the 24 position ${ }^{(56)}$. Anderson et al. ${ }^{(57)}$ have used the technique of real-time RT-PCR to determine mRNA for both enzymes in the kidneys from animals exposed to different dietary $\mathrm{Ca}^{2+}$ concentrations. The levels of CYP27B1 mRNA were highest in the animals fed a low- $\mathrm{Ca}^{2+}$ diet and, conversely, the CYP24 mRNA levels were highest in animals with higher
$\mathrm{Ca}^{2+}$ intake. These authors did not find a correlation between PTH and renal CYP27B1 mRNA levels in animals fed a vitamin D-replete diet, which suggests that serum $\mathrm{Ca}^{2+}$ may regulate CYP27B1 directly in conditions of normal blood $\mathrm{Ca}^{2+}$ levels. Thus, the transcription of CYP27B1 in vivo seems to be enhanced by PTH only in hypocalcaemic rats, but not in normocalcaemic animals.

Endogenous production of $1,25(\mathrm{OH})_{2} \mathrm{D}_{3}$, induced by a low- $\mathrm{Ca}^{2+}$ diet, can raise hormone levels four or five times above normal values without suppression of CYP27B1 $1^{(31)}$. A decrease in the renal VDR content, which drops to $20 \%$ of control after prolonged dietary $\mathrm{Ca}^{2+}$ deficiency, could explain this effect ${ }^{(58)}$. Bajwa et al. ${ }^{(59)}$ have determined the differences in renal cortex gene expression between rats fed a low- $\mathrm{Ca}^{2+} \operatorname{diet}\left(0.02 \% \mathrm{Ca}^{2+}\right)$ and those fed a normal- $\mathrm{Ca}^{2+}$ diet $\left(0.47 \% \mathrm{Ca}^{2+}\right)$ and treated with two sequential $1 \mu \mathrm{g}$ doses of calcitriol, by using the GeneChip oligonucleotide microarray technology and real-time RT-PCR to confirm the data. CaR was unaffected whereas PTH receptor-1 was increased (1.8-fold) by the low- $\mathrm{Ca}^{2+}$ diet. In contrast, intracellular vitamin D-binding protein, VDR, calbindin $\mathrm{D}_{28 \mathrm{k}}$, osteopontin and 24-OHase were all low under the same mineral condition. As expected, the $1 \alpha-\mathrm{OH}$ ase gene was up-regulated by the low- $\mathrm{Ca}^{2+}$ diet. Surprisingly, the expression of secreted phosphoprotein-24 and the transcription factors such as cAMP response element binding protein (CREB) and GATA binding protein globin 1 transcription factor 1 (GATA-1) were increased by the low- $\mathrm{Ca}^{2+}$ diet. The authors hypothesised that the cAMP-protein kinase A pathway is a distinctive feature of low $\mathrm{Ca}^{2+}$ in response to 
increased PTH. As VDR decreases by a low- $\mathrm{Ca}^{2+}$ diet, epithelial cells of the proximal tubules become refractory to enhanced calcitriol synthesis.

Patients with renal lithiasis may be at higher risk of recurrence of stone formation when they have $\mathrm{Ca}^{2+}$ intakes below the RDA. Although the restriction of $\mathrm{Ca}^{2+}$ decreases urinary excretion of the cation, intestinal oxalate absorption increases and the formation of stones due to secondary hyperoxaluria is enhanced. Health professionals must be aware of this, mainly with female patients who may develop osteoporotic complications and bone fractures because of dietary $\mathrm{Ca}^{2+}$ deficiency ${ }^{(60)}$. The response of the stone formers to low- $\mathrm{Ca}^{2+}$ diets seems to be dependent on BMD. Pasch et al. ${ }^{(61)}$ have observed that when these patients have low lumbar BMD, they exhibit a blunted response of PTH release and an enhanced production of $1,25(\mathrm{OH})_{2} \mathrm{D}_{3}$ after a low- $\mathrm{Ca}^{2+}$ diet. On the contrary, when patients have high lumbar BMD, PTH levels are highly increased after a dietary $\mathrm{Ca}^{2+}$ restriction. The reason for a large concentration of $1,25(\mathrm{OH})_{2} \mathrm{D}_{3}$ in the absence of a PTH response to a low- $\mathrm{Ca}^{2+}$ diet in stone-former patients with low BMD has been assumed to be reminiscent of a dynamic bone disease. The authors speculate that these patients might have normal or exaggerated intestinal $\mathrm{Ca}$ absorption because of $1,25(\mathrm{OH})_{2} \mathrm{D}_{3}$ enhancement, but they are not able to deposit the extra $\mathrm{Ca}^{2+}$ into their bones due to the primary bone problem and, hence, calciuria increases, facilitating stone formation.

\section{Relationship between dietary $\mathrm{Ca}^{2+}$ and lipid metabolism}

As MacDonald says if asked about a link between milk intake and weight in the past, the likely conclusion was that dairy was 'fattening' (62). However, with the pioneering work of Zemel ${ }^{(63)}$, it has been understood that an energyrestricted diet with the inclusion of at least three servings of dairy per $d$ will help to attain the ideal weight. Mirmiran et al. (64) have also shown that there is an inverse relationship between dairy intake and BMI. The role of dietary $\mathrm{Ca}^{2+}$ on the regulation of lipid metabolism and lipogenic genes in adipocytes constitutes the molecular basis that might explain the results of nutritional trials. Several years ago, it was found that Agouti, an obesity gene expressed in human adipocytes, produces a protein which stimulates $\mathrm{Ca}^{2+}$ influx and energy storage in human adipocytes by $\mathrm{Ca}^{2+}$-dependent stimulation of fatty acid synthase and inhibition of lipolysis ${ }^{(65,66)}$. Calcitriol treatment of human adipocytes has been proved to activate fatty acid synthase and to inhibit lipolysis in a similar way to that done by agouti protein in these cells ${ }^{(67)}$. Therefore, suppression of calcitriol with high- $\mathrm{Ca}^{2+}$ diets would produce an anti-obesity effect. In fact, this has been demonstrated in transgenic mice overexpressing Agouti in adipocytes under the control of the aP2 promoter, mimicking the human expression pattern. Those mice placed on a low- $\mathrm{Ca}^{2+}$-high-fat-high-sucrose diet for 6 weeks showed increases in adipocyte lipogenesis, decreases in lipolysis and increments in body weight and adipose tissue mass. All these responses were partially reversed by high- $\mathrm{Ca}^{2+}$ diets, the reversion being more successful with dairy sources of $\mathrm{Ca}^{2+}$ than with $\mathrm{Ca}_{2}\left(\mathrm{PO}_{4}\right)_{3}$. In a recent review about $\mathrm{Ca}^{2+}$-related obesity research ${ }^{(68)}$, the authors discussed the different milk or dairy components that contribute to the impact of dairy $\mathrm{Ca}^{2+}$ on body weight. First of all, milk proteins are more satiating than fat and carbohydrates and are often found to suppress appetite and intake. Proteins of whey and casein reduce food intake, and stimulate biomarkers of satiety including gastrointestinal hormones, insulin and amino acids. Peptides derived from whey and casein are inhibitors of the reninangiotensin system; this can explain the inverse relationship between blood pressure and dietary $\mathrm{Ca}^{2+}$. Thus, dairy proteins in addition to $\mathrm{Ca}^{2+}$ content may have a role in glycaemic control and the metabolic syndrome.

Several pathologies associated with $\mathrm{Ca}^{2+}$ deficiency have shown an increase in intracellular $\mathrm{Ca}^{2+}$ concentration in the presence of a low serum $\mathrm{Ca}^{2+}$. This is referred to as the "calcium paradox ${ }^{\text {(69) }}$. A possible explanation of this response would be that the increase of $1,25(\mathrm{OH})_{2} \mathrm{D}_{3}$, promoted by a low- $\mathrm{Ca}^{2+}$ diet, produces stimulation of $\mathrm{Ca}^{2+}$ influx in the cells, as shown by Zemel et al. ${ }^{(67)}$ in cultures of human adipocytes. This increase in intracellular $\mathrm{Ca}^{2+}$ concentration stimulates fat storage by the activation of fatty acid synthase and inhibition of lipolysis by the activation of phosphodiesterse $3 \mathrm{~B}$, which leads to a decrease in cAMP, reducing the ability of agonists to stimulate hormone-sensitive lipase ${ }^{(70)}$.

Another mechanism triggered by low- $\mathrm{Ca}^{2+}$ diets is an impairment in adipocyte apoptosis, which is attributed to high levels of $1,25(\mathrm{OH})_{2} \mathrm{D}_{3}$. In contrast, mice fed high-Ca and/or high-dairy diets exhibit a marked enhancement in adipocyte apoptosis. This is apparently contrary to many published reports showing pro-apoptotic effects of calcitriol in other tissues ${ }^{(71,72)}$. Sun \& $\mathrm{Zemel}^{(73)}$ attribute this discrepancy to dosing differences because the pro-apoptotic effects of calcitriol are as a result of employing supraphysiological concentrations of calcitriol ( $\geq 100 \mathrm{~nm}$ ), while the anti-apoptotic effect of calcitriol on human adipocytes was observed with physiological concentrations. Furthermore, the anti-apoptotic effects, apparently due to suppression of uncoupling protein 2 expression, were reversed by pharmacological doses of calcitriol in human adipocytes ${ }^{(73)}$. It is of interest to note that adipocyte apoptosis has not been extensively studied. One of the main difficulties is that adipocytes have a very low nuclear:cytoplasmic ratio, which restricts the identification of apoptotic cells and comparisons of apoptotic rates ${ }^{(74)}$. Nevertheless, adipocyte apoptosis has been demonstrated to occur by leptin treatment, which would act through NF- $\kappa \mathrm{B}$ activation and increased levels of PPAR $\gamma$ inducing transcription of pro-apoptotic factors $^{(75)}$.

The dysregulation of glucocorticosteroid metabolism is another alteration that has been proposed to be triggered by low- $\mathrm{Ca}^{2+}$ diets in adipose tissue. Morris \& $\mathrm{Zemel}^{(76)}$ have demonstrated an increase in 11- $\beta$-hydroxysteroid dehydrogenase type I activity in human adipocytes treated with $1,25(\mathrm{OH})_{2} \mathrm{D}_{3}$. This enzyme converts cortisone to active cortisol. Its expression is greater in visceral adipose tissue than in subcutaneous fat. Consequently, these authors propose that dietary $\mathrm{Ca}^{2+}$ restriction might contribute to visceral fat through an increment in cortisol production induced by $1,25(\mathrm{OH})_{2} \mathrm{D}_{3}$, in addition to the fatty acid synthase activation already mentioned. A strong inverse 
association between $\mathrm{Ca}^{2+}$ intake and abdominal adiposity (total abdominal fat, abdominal visceral fat, abdominal subcutaneous fat, waist circumference) was found in black men and white women of the HERITAGE (Health, Risk factors, exercise Training And Genetics) Family Study ${ }^{(77)}$. A similar finding was reported for women of the Québec Family Study ${ }^{(78)}$. However, not all studies found an inverse association between $\mathrm{Ca}^{2+}$ intake and adiposity ${ }^{(79)}$. Recently, Heiss et al. ${ }^{(80)}$ determined lean and fat mass by dual-energy X-ray absorptiometry (DXA) and defined abdominal fat as fat mass between the top of the iliac crest and L1 on the DXA scan in Caucasian postmenopausal women. They observed that there was a significant inverse relationship between $\mathrm{Ca}$ intake and percentage body fat and abdominal fat mass, but there was no significant correlation between $\mathrm{Ca}$ intake and BMI, fat mass, lean mass, waist circumference or waist:hip ratio. They found that total fat was greater in the low dairy intake group $v$. the high dairy intake group, but they did not find significant differences between the groups in other body composition variables.

\section{Association between hypertension and dietary $\mathrm{Ca}^{2+}$ deficiency}

The history that dietary $\mathrm{Ca}^{2+}$ might have a meaningful impact on blood pressure regulation started a long time ago ${ }^{(81,82)}$. In the early 1980 s, two publications by McCarron et al. ${ }^{(83,84)}$ showed that low-Ca ${ }^{2+}$ diets were associated with hypertension and that dietary $\mathrm{Ca}^{2+}$ consumption by US adults was inversely related to the possibility of developing hypertension. A meta-analysis of forty-two clinical trials demonstrated significant blood pressure reduction by increasing $\mathrm{Ca}^{2+}$ intake either in non-pregnant populations as well as pregnancy-induced hypertension and preeclampsia ${ }^{(85)}$. The anti-hypertensive effect of $\mathrm{Ca}^{2+}$ appears to be paradoxical because $\mathrm{Ca}^{2+}$ supplementation leads to a reduction in systolic and diastolic blood pressure ${ }^{(86)}$, whereas an increase of intracellular $\mathrm{Ca}^{2+}$ enhances vascular smooth muscle tone, peripheral vascular resistance and blood pressure. The protective effect of $\mathrm{Ca}^{2+}$ on blood pressure could be explained through the stimulation of the vitamin $\mathrm{D}$ endocrine system. Low- $\mathrm{Ca}^{2+}$ diets increase circulating levels of $1,25(\mathrm{OH})_{2} \mathrm{D}_{3}$, which stimulates $\mathrm{Ca}^{2+}$ influx into vascular smooth muscle cells, thereby increasing vascular tone and blood pressure. In contrast, high-Ca ${ }^{2+}$ diets reduce the stimulus for $\mathrm{Ca}^{2+}$ influx by suppressing $1,25(\mathrm{OH})_{2} \mathrm{D}_{3}$ production. Certain heterogeneity of response in blood pressure to dietary $\mathrm{Ca}^{2+}$ has been noted, saltsensitive patients being those who have most consistently exhibited anti-hypertensive responses ${ }^{(87,88)}$. The Dietary Approaches to Stop Hypertension (DASH) study has demonstrated that a food consumption pattern rich in lowfat dairy products and in fruits and vegetables produces hypotensive effects comparable with those found in pharmacological trials of mild hypertension ${ }^{(89)}$. This study tested the effects of dietary patterns rather than individual nutrients on blood pressure. The authors think that the inconsistency of data from different trials may result from analysing a single nutrient, which could produce small blood pressure-lowering effects. They showed that either in subjects with hypertension or in those without hypertension, the combined diet reduced blood pressure more than the fruits-and-vegetables or the control diets. Furthermore, the interaction between hypertensive status and diet was higher for systolic blood pressure than for diastolic blood pressure. Thus, adoption of the DASH combination diet might prevent or delay the initiation of drug therapy in individuals at the threshold for drug treatment. Recently, a large prospective cohort study of middle-aged and older women has shown an inverse association between low-fat dairy product intake and the subsequent risk of hypertension. This association was moderate and independent of other risk factors for hypertension, but it was not observed between high-fat dairy intake and the risk of hypertension ${ }^{(90)}$. Previously, by using a validated semi-quantitative FFQ, Alonso et al. ${ }^{(91)}$ had shown in Spanish adult men and women that the highest quintile of low-fat dairy consumption was associated with a reduction of $54 \%$ in the risk of hypertension, while high-fat dairy consumption was not associated with the incidence of hypertension. The reason for this remains unclear. High-fat dairy products might hinder $\mathrm{Ca}^{2+}$ absorption because $\mathrm{Ca}^{2+}$ forms soaps with the fatty acids, reducing the bioavailability of $\mathrm{Ca}^{2+}$. Another possibility is that changes in the nutritional composition of the skimmed milk and whole milk during processing and preparation (less amount of fat, loss of $\mathrm{Ca}^{2+}$ in soluble form, proteins and appearance of encrypted peptides with hypotensive potential) ${ }^{(92,93)}$ could explain the differences, but this has not been confirmed ${ }^{(90)}$. Regarding molecular mechanisms, it has been shown that dietary $\mathrm{Ca}^{2+}$ may lower the activity of the reninangiotensin system ${ }^{(94)}$ and inhibit vascular smooth muscle cell constriction ${ }^{(95)}$. Besides, $\mathrm{Ca}^{2+}$ facilitates weight loss ${ }^{(96)}$ and stimulates insulin sensitivity ${ }^{(97)}$, which contribute to decreases in blood pressure.

It remains unclear whether the $\mathrm{Ca}^{2+}$ content alone or in combination with several components such as other minerals or proteins, peptides or amino acids are responsible for the anti-hypertensive effects of dairy products ${ }^{(96)}$. High levels of $\mathrm{Ca}^{2+}, \mathrm{K}^{+}$and $\mathrm{Mg}^{2+}$ seem to be favourable but data are not conclusive ${ }^{(98)}$. It is quite possible that interactions among different minerals present in milk or dairy products as well as additive effects of milk compounds on hypertension could explain the benefits of dietary patterns (DASH study) as compared with supplementations of isolated nutrients.

\section{Nutritional $\mathrm{Ca}^{2+}$ and risk of colon, breast, prostate and ovarian cancer}

Evidence that dietary $\mathrm{Ca}^{2+}$ is associated with colorectal cancer has come from case-control studies, prospective cohort studies and some clinical trials ${ }^{(99)}$. Cohort studies have detected that milk and dairy products have a protective effect on colorectal cancer ${ }^{(99)}$. The mechanisms involved in this effect would be a decrease in cell proliferation or promotion in cell differentiation ${ }^{(100)}$. Three cohort studies demonstrated a modest effect of $\mathrm{Ca}^{2+}$ on colorectal cancer risk reduction ${ }^{(101-103)}$. Another study demonstrated that high consumption of milk might reduce colon cancer risk, but not because of the $\mathrm{Ca}^{2+}$ and vitamin $\mathrm{D}$ content ${ }^{(104)}$. Hofstad et al. ${ }^{(105)}$ have found that a 3-year intervention with $\mathrm{Ca}^{2+}$ and antioxidants had no effect on polyp growth, but it 
might have a protective effect in avoiding formation of new adenomas. Grau et al. ${ }^{(106)}$ have found that the combination of $\mathrm{Ca}^{2+}$ and vitamin $\mathrm{D}$ reduces the risk of colorectal adenomas. Case-control studies have produced contradictory data. Some of them have demonstrated that $\mathrm{Ca}^{2+}$ intake is associated with a reduced risk of colorectal cancer $^{(107,108)}$, but others have not ${ }^{(109,110)}$. Recent pooled analysis and epidemiological studies have demonstrated an inverse relationship between $\mathrm{Ca}^{2+}$ intake and colorectal cancer or adenoma risk ${ }^{(111,112)}$. Furthermore, randomised clinical trials have shown that $\mathrm{Ca}^{2+}$ supplementation reduces adenoma risk $^{(113,114)}$.

Induction of colonic hyperproliferation and expansion of an epithelial cell population containing atypical nuclei have been found in experimental animals such as rats and mice fed Western-style diets (high fat, low $\mathrm{Ca}^{2+}$, low vitamin D, low fibre $)^{(115)}$. When this feeding was prolonged, markers of incipient tumorigenesis such as dysplastic lesions and focal hyperplasia appeared. Cyclo-oxygenase (Cox)-2 protein, an inducible enzyme that is frequently overexpressed in inflamed tissues and in colorectal cancer, has also been found to be enhanced by dietary $\mathrm{Ca}^{2+}$ deficiency, mainly in females $^{(115)}$. Although the molecular mechanisms by which dietary $\mathrm{Ca}^{2+}$ influences colonic health remain unknown, Pele et al. ${ }^{(116)}$ propose three possibilities: (1) dietary $\mathrm{Ca}^{2+}$ could alter the ratio of faecal bile acids, decreasing the water-soluble bile acids and reducing the cytotoxicity of faecal water; (2) $\mathrm{Ca}_{3}\left(\mathrm{PO}_{4}\right)_{2}$ particles could bind luminal antigens, transporting them into mucosal mononuclear cells as a mechanism of immunosurveillance and promotion of tolerance; and (3) dietary $\mathrm{Ca}^{2+}$ could activate $\mathrm{CaR}$, triggering intracellular signalling pathways, among them proliferative and apoptotic pathways. Several pathways are activated by $\mathrm{Ca}^{2+}$ through $\mathrm{CaR}$, including activation of the p38 mitogen-activated protein kinase cascade, promotion of E-cadherin (tumour suppressor) and suppression of $\beta$ catenin/T cell factor binding (a process that promotes a malignant phenotype $)^{(117,118)}$.

Data relative to nutritional $\mathrm{Ca}^{2+}$ and incidences of human cancers of the breast, prostate and pancreas are also controversial $^{(119)}$. In a large prospective study, a high intake of $\mathrm{Ca}^{2+}$ and low-fat dairy products was found to be associated with a moderately lower risk of developing postmenopausal breast cancer as compared with women with the lowest intake levels. Interestingly, supplemental $\mathrm{Ca}$ or higher levels of total $\mathrm{Ca}$ (diet plus supplements) or vitamin $\mathrm{D}$ were not related to overall breast cancer risk ${ }^{(5)}$. Human mammary epithelial (HME) cells exhibit VDR and CYP27B1 and show growth inhibition after exposure to physiological doses of $25 \mathrm{OHD}_{3}$, which indicates that autocrine or paracrine vitamin D signalling is involved in the maintenance of differentiation and quiescence of the mammary epithelium ${ }^{(120)}$. Oncogenic transformations of HME cells through introduction of known oncogenes (SV40 $\mathrm{T}$ antigens and $\mathrm{H}$-rasV12) were associated with a reduction in mRNA and protein levels of VDR and CYP27B1. In addition, the transformation was also found to be associated with a reduction in $1,25(\mathrm{OH})_{2} \mathrm{D}_{3}$ synthesis and in the cellular sensitivity to growth inhibition caused by either $1,25(\mathrm{OH})_{2} \mathrm{D}_{3}$ or $25 \mathrm{OHD}_{3}$. These changes indicate that disruption of the vitamin $\mathrm{D}$ signalling pathway occurs early in cancer development ${ }^{(120)}$. Although the mechanisms involved in breast carcinogenesis induced by low-Ca ${ }^{2+}$ diets remain unknown, it is quite possible that dietary $\mathrm{Ca}^{2+}$ deficiency causes a dysregulation in the vitamin D endocrine system, which may result in a reduction in the response of breast cells to calcitriol and a promotion of oncogenic transformation. Calcitriol synthesis is increased by a secondary hyperparathyroidism provoked by hypocalcaemia $^{(32)}$ and the continuous high exposure of breast cells to calcitriol may reduce the sensitivity of cells to the hormone. This could be due, at least in part, to downregulation of VDR expression. High levels of circulating PTH would promote bone resorption. Growth factors such as transforming growth factor $\beta$ and IGF might be released from the bone matrix, promoting tumour growth ${ }^{(49)}$. The activation of proto-oncogenes and/or inactivation of tumour suppressor genes as local carcinogenic stimuli could also contribute to the initiation of transformation of normal breast cells into malignant breast cells. Further experiments are needed in order to know the mechanisms by which dietary $\mathrm{Ca}^{2+}$ deficiency could contribute to the early steps of breast cancer development. As mentioned above, the growth of breast cancer tumours implanted in bone was promoted in experimental animals with accelerated bone resorption caused by low-Ca ${ }^{2+}$ diets ${ }^{(49)}$.

Giovanucci et al. ${ }^{(6)}$ have found an association between high $\mathrm{Ca}^{2+}$ intake and a higher risk of high-grade prostate cancer (Gleason histological grade $>7$ ), but not with welldifferentiated organ-confined cancers. However, neither the development nor progression of prostate tumours in mice was enhanced by high- $\mathrm{Ca}^{2+}$ diets ${ }^{(121)}$. Through a randomised controlled clinical trial, Baron et al. ${ }^{(122)}$ demonstrated that there was no increase in prostate cancer risk associated with $\mathrm{Ca}^{2+}$ supplements, and they raised the possibility that $\mathrm{Ca}^{2+}$ may instead lower the risk of this cancer. Recently, Torniainen et al. ${ }^{(123)}$ showed some evidence for low-fat milk as a potential risk factor for prostate cancer in patients from Nordic countries. Bonjour et al. ${ }^{(124)}$ concluded that the link between $\mathrm{Ca}^{2+}$ and the development of prostate cancer remains a hypothesis, which is not supported so far by clinical data.

Epidemiological studies indicate that low- $\mathrm{Ca}^{2+}$ diets are risk factors for pancreatic cancer ${ }^{(125)}$. However, two recent prospective cohort studies have demonstrated that the inverse relationship between $\mathrm{Ca}^{2+}$ intake and the risk for pancreatic cancer is attenuated by adjusting for vitamin $\mathrm{D}$ intake. In contrast, vitamin D consumption has a significant inverse relationship with pancreatic cancer risk $^{(126)}$. Clinical characteristics of patients need to be carefully controlled in these studies. Stolzenberg-Solomon et al. ${ }^{(127)}$ conducted a prospective nested case-control study in male Finnish smokers (aged 50-69 years at baseline) to test whether prediagnostic $25 \mathrm{OHD}_{3}$ concentrations were associated with lower pancreatic cancer risk. Contrary to their expectations, they found that subjects with higher vitamin D status had an increased pancreatic cancer risk. Recently, they did not confirm that strong association between $25 \mathrm{OHD}_{3}$ and pancreatic cancer, adjusting for smoking and BMI, but they found an association between low estimated annual residential solar UVB exposure and cancer risk ${ }^{(128)}$ 


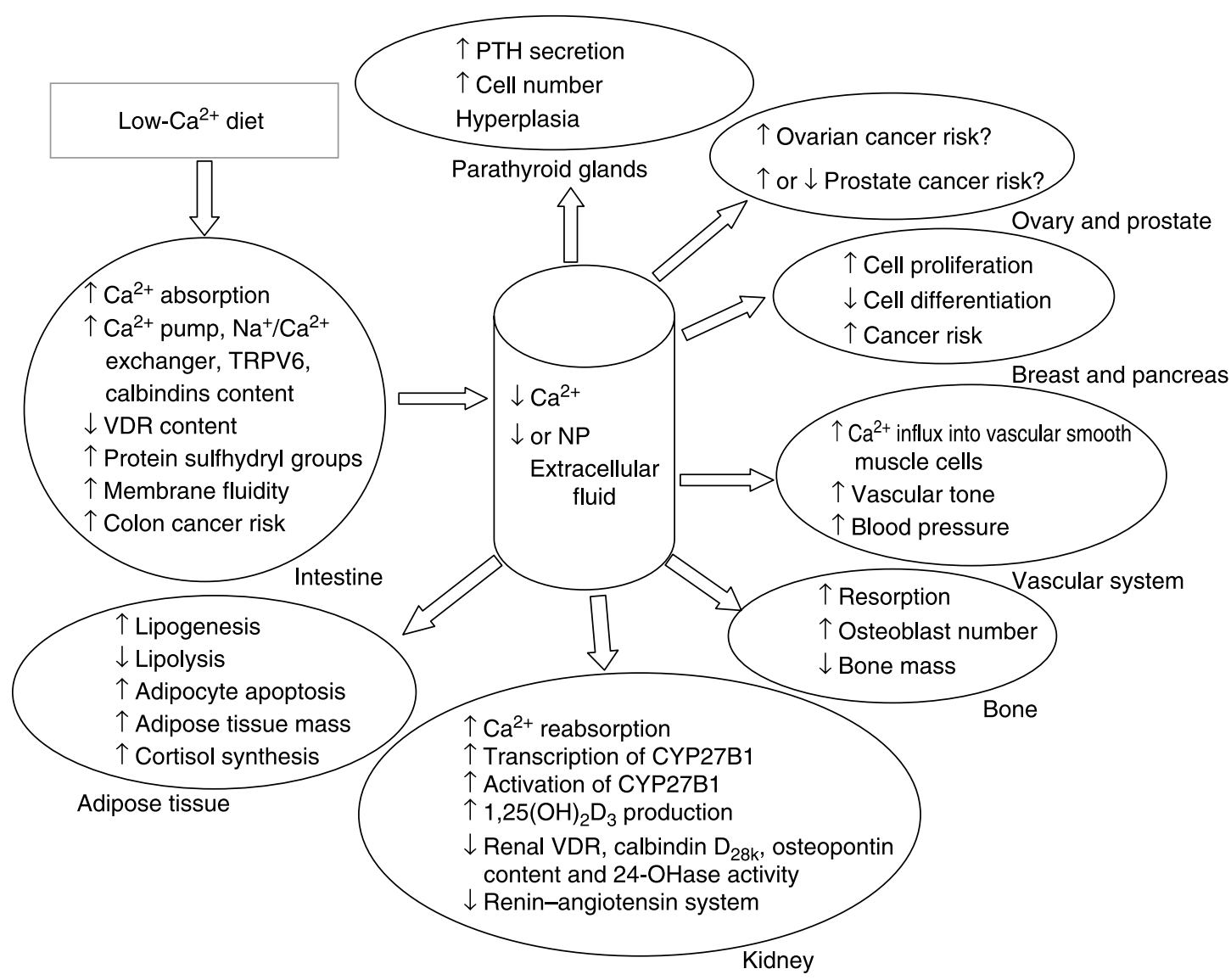

Fig. 2. Metabolic changes caused by low- $\mathrm{Ca}^{2+}$ diets on different organs and tissues. TRPV6, transient receptor potential cation channel, subfamily V, member 6; VDR, vitamin D receptor; PTH, parathyroid hormone; NP, normal phosphate; CYP27B1, 25-OH-cholecalciferol 1-hydroxylase; $1,25(\mathrm{OH})_{2} \mathrm{D}_{3}, 1,25$-dihydroxyvitamin $\mathrm{D}_{3}$.

The association between risk of ovarian cancer and milk or dairy food intake is not clear either. The disaccharide lactose, naturally present as a component of milk and dairy products, is hydrolysed by the intestinal lactase into glucose and galactose. It was thought that galactose levels could be related to the risk of ovarian cancer because high circulating galactose may impair ovarian feedback to the pituitary gland, increasing gonadotropin secretion, which may increase oestrogenic stimulation, resulting in proliferation of ovarian epithelium ${ }^{(129)}$. This has been named the galactose-gonadotropin hypothesis. However, several authors did not find any correlation between the risk of developing ovarian cancer and dairy food intake, daily galactose consumption or the prevalence of low activity of galactose-1-phosphate-uridyltransferase or lactase persistence $^{(130,131,132)}$. In a case-control study in Hawaii and Los Angeles to examine several dietary hypotheses related to the aetiology of ovarian cancer, it was found that the intake of low-fat milk, $\mathrm{Ca}^{2+}$ or lactose may reduce the risk of ovarian cancer $^{(130)}$. An association between ovarian cancer risk and a high whole milk intake, but not low-fat dairy product intake, suggested that fat, and not galactose, was the component that increases the cancer risk ${ }^{(133)}$. Contrarily, a cohort study on diet and cancer carried out in The Netherlands ${ }^{(134)}$ did not find an association between dairy products or lactose intake and ovarian cancer risk. A modest increase in the risk of ovarian cancer with lactose intake at the level of three or more glasses of milk per d was observed in a pooled analysis of twelve cohort studies ${ }^{(135)}$. The authors of this study suggested that dairy product consumption in relation to ovarian cancer risk should be further examined. Based on considerations described above, a schematic representation of the main metabolic changes caused by low-Ca ${ }^{2+}$ diets is summarised in Fig. 2 .

\section{Concluding remarks}

Although low- $\mathrm{Ca}^{2+}$ diets trigger adaptive mechanisms in order to maintain extracellular $\mathrm{Ca}^{2+}$ concentration and ensure $\mathrm{Ca}^{2+}$-dependent cellular functions, they also alter many metabolic pathways, whose persistence may lead to pathological conditions. The efficiency of intestinal $\mathrm{Ca}^{2+}$ absorption is increased due to the increment in renal calcitriol synthesis induced mainly by high levels of serum PTH. This calciotropic hormone promotes bone loss and, when $\mathrm{Ca}^{2+}$ deficiency occurs in childhood and adolescence, the attainability of peak bone mass is not reached. The association of low-Ca ${ }^{2+}$ diets with osteoporosis development is very weak, but, apparently, interactions between nutritional $\mathrm{Ca}^{2+}$ and vitamin $\mathrm{D}$ with physical activity seem to be important along the lifespan either to increase peak bone mass or to delay bone loss in the elderly. Lipid 
metabolism and lipogenic genes are altered in adipocytes as well as cortisol production, which might contribute to increased visceral fat. Circulating levels of $1,25(\mathrm{OH})_{2} \mathrm{D}_{3}$ stimulate $\mathrm{Ca}^{2+}$ influx into vascular smooth muscle cells, thereby increasing vascular tone and blood pressure. Proliferative and apoptotic pathways might be dysregulated, leading to the development and progression of malignancies such as colon, breast, prostate and ovarian cancers. Health professionals should be aware of these nutritional complications and reinforce the dairy intakes in individuals of all ages to ensure the recommended $\mathrm{Ca}^{2+}$ requirements and prevent diseases associated with poor $\mathrm{Ca}^{2+}$ intake.

N. T. de T. is a member of the Investigator Career from the Consejo Nacional de Investigaciones Científicas y Tecnológicas (CONICET). V. C. is a postdoctoral fellow from Secretaría de Ciencia y Técnica de la Universidad Nacional de Córdoba (SECYT-UNC). V. R. is a doctoral fellow from CONICET.

The present study was supported by Fondo para la Investigación Científica y Tecnológica (FONCyT; PICT 2005-32464), CONICET (PIP 2005-6) and SECYT-UNC, all in Argentina.

Each author has contributed to literature searching, information analysis, discussion and writing of the present paper.

There are no conflicts of interest.

\section{References}

1. Ma J, Johns RA \& Stafford RS (2007) Americans are not meeting current calcium recommendations. Am J Clin Nutr 85, 1361-1366.

2. Petre-Lazar B, Livera G, Moreno SG, et al. (2007) The role of p63 in germ cell apoptosis in the developing testis. J Cell Physiol 210, 87-98.

3. Li M, Kondo T, Zhao QL, et al. (2000) Apoptosis induced by cadmium in human lymphoma U937 cells through $\mathrm{Ca}^{2+}$. calpain and caspase-mitochondria-dependent pathways. J Biol Chem 275, 39702-39709.

4. Zemel MB (2001) Calcium modulation of hypertension and obesity: mechanisms and implications. J Am Coll Nutr 20, 428S-435S.

5. McCullough ML, Rodriguez C, Diver WR, et al. (2005) Dairy, calcium, and vitamin D intake and postmenopausal breast cancer risk in the Cancer Prevention Study II Nutrition Cohort. Cancer Epidemiol Biomarkers Prev 14, 2898-2904.

6. Giovannucci E, Liu Y, Stampfer MJ, et al. (2006) A prospective study of calcium intake and incident and fatal prostate cancer. Cancer Epidemiol Biomarkers Prev 15, 203-210.

7. Huncharek M, Muscat J \& Kupelnick B (2009) Colorectal cancer risk and dietary intake of calcium, vitamin D and dairy products: a meta-analysis of 26335 cases from 60 observational studies. Nutr Cancer 61, 47-69.

8. Lipkin M (1999) Preclinical and early human studies of calcium and colon cancer prevention. Ann N Y Acad Sci 889, $120-127$.
9. Kranz S, Lin PJ \& Wagstaff DA (2007) Children's dairy intake in the United States: too little, too fat? J Pedriatr 151, 642-646.

10. Ulla M, Perez A, Elias V, et al. (2007) Genotypes of vitamin $\mathrm{D}$ and estrogen receptors in pre and perimenopausal women from Cordoba, Argentina. Medicina 67, 32-38.

11. Gilis-Januszewska A, Topór-Madry R \& Pajak A (2003) Education and the quality of diet in women and men at age 45-64, in Cracow. Przegl Lek 60, 675-681.

12. Lyytikäinen A, Lamberg-Allardt C, Kannas L, et al. (2005) Food consumption and nutrient intakes with a special focus on milk product consumption in early pubertal girls in Central Finland. Public Health Nutr 8, 284-289.

13. Olsen SF, Dragsted LO, Hansen HS, et al. (2005) The scientific basis of current official dietary recommendations in relation to pregnancy. Ugeskr Laeger 167, 2782-2784.

14. Bhatia V (2008) Dietary calcium intake - a critical reappraisal. Indian J Med Res 127, 269-273.

15. Pérez A, Ulla M, García B, et al. (2008) Genotypes and clinical aspects associated with bone mineral density in Argentine postmenopausal women. J Bone Miner Metab 26, $358-365$.

16. Tolosa de Talamoni NG (1996) Calcium and phosphorous deficiencies alter the lipid composition and fluidity of intestinal basolateral membranes. Comp Biochem Physiol A Physiol 115, 309-315.

17. Centeno VA, Díaz de Barboza GE, Marchionatti AM, et al. (2004) Dietary calcium deficiency increases $\mathrm{Ca}^{2+}$ uptake and $\mathrm{Ca}^{2+}$ extrusion mechanisms in chick enterocytes. Comp Biochem Physiol A Mol Integr Physiol 139, 133-141.

18. Tolosa de Talamoni N \& Centeno V (1999) Low calcium diets in humans and in experimental animals: classic models to understand calcium homeostasis and vitamin D endocrine systems. Endocrinologia 46, 241-244.

19. O'Brien KO, Abrams SA, Liang LK, et al. (1996) Increased efficiency of calcium absorption during short periods of inadequate calcium intake in girls. Am J Clin Nutr 63, $579-583$.

20. Swaminathan R, Sommerville BA \& Care AD (1977) The effect of dietary calcium on the activity of 25-hydroxycholecalciferol-1-hydroxylase and $\mathrm{Ca}$ absorption in vitamin D-replete chicks. Br J Nutr 38, 47-54.

21. Hanley DA, Takatsuki K, Birnbaumer ME, et al. (1980) In vitro perifusion for the study of parathyroid hormone secretion: effects of extracellular calcium concentration and $\beta$-adrenergic regulation on bovine parathyroid hormone secretion in vitro. Calcif Tissue Int 32, 19-27.

22. Hughes MR, Brumbaugh PF, Hussler MR, et al. (1975) Regulation of serum 1 $\alpha, 25$-dihydroxyvitamin $\mathrm{D}_{3}$ by calcium and phosphate in the rat. Science 190, 578-580.

23. Schedl HP, Conway T, Horst RL, et al. (1996) Effects of dietary calcium and phosphorus on vitamin D metabolism and calcium absorption in hamster. Proc Soc Exp Biol Med 211, 281-286.

24. Vieth R, Fraser D \& Kooh SW (1987) Low dietary calcium reduces 25 -hydroxycholecalciferol in plasma of rats. $J$ Nutr 117, 914-918.

25. Gascon-Barré M, D'Amour P, Dufresne L, et al. (1985) Interrelationships between circulating vitamin D metabolites in normocalciuric and hypercalciuric renal stone formers. Ann Nutr Metab 29, 289-296.

26. Fleet JC, Gliniak C, Zhang Z, et al. (2008) Serum metabolite profiles and target tissue gene expression define the effect of cholecalciferol intake on calcium metabolism in rats and mice. J Nutr 138, 1114-1120. 
27. Christakos S, Dhawan P, Liu Y, et al. (2003) New insights into the mechanisms of vitamin D action. $J$ Cell Biochem 88, 695-705.

28. Brown AJ, Krits I \& Armbrecht HJ (2005) Effect of age, vitamin $\mathrm{D}$, and calcium on the regulation of rat intestinal epithelial calcium channels. Arch Biochem Biophys 437, 51-58.

29. Wasserman RH, Smith CA, Brindak ME, et al. (1992) Vitamin D and mineral deficiencies increase the plasma membrane calcium pump of chicken intestine. Gastroenterology 102, 886-894.

30. Fox J, Bunker JE, Kamimura M, et al. (1990) Low-calcium diets increase both production and clearance of 1,25dihydroxyvitamin $\mathrm{D}_{3}$ in rats. Am $J$ Physiol 258, E282-E287.

31. Goff JP, Reinhardt TA, Engstrom GW, et al. (1992) Effect of dietary calcium or phosphorus restriction and 1,25dihydroxyvitamin D administration on rat intestinal 24hydroxylase. Endocrinology 131, 101-104.

32. Naveh-Many T, Rahamimov R, Livni N, et al. (1995) Parathyroid cell proliferation in normal and chronic renal failure rats. The effects of calcium, phosphate, and vitamin D. J Clin Invest 96, 1786-1793.

33. Brown EM, Gamba G, Riccardi D, et al. (1993) Cloning and characterization of an extracellular $\mathrm{Ca}^{2+}$-sensing receptor from bovine parathyroid. Nature 366, 575-580.

34. Chattopadhyay N (2006) Effects of calcium-sensing receptor on the secretion of parathyroid hormone-related peptide and its impact on humoral hypercalcemia of malignancy. Am J Physiol Endocrinol Metab 290, E761-E770.

35. Díaz R, El-Hajj G \& Brown E (2000) Parathyroid hormone and poly hormones: production and export. In Handbook of Physiology: Endocrine Regulation of Water and Electrolyte Balance, pp. 607-662 [Y Fray, editor]. New York: Oxford University Press.

36. Bas S, Bas A, López I, et al. (2005) Nutritional secondary hyperparathyroidism in rabbits. Domest Anim Endocrinol 28, 380-390.

37. Brown EM (1983) Four-parameter model of the sigmoidal relationship between parathyroid hormone release and extracellular calcium concentration in normal and abnormal parathyroid tissue. J Clin Endocrinol Metab 56, 572-581.

38. Kanesaka Y, Tokunaga H, Iwashita K, et al. (2001) Endothelin receptor antagonist prevents parathyroid cell proliferation of low calcium diet-induced hyperparathyroidism in rats. Endocrinology 142, 407-413.

39. Miao D, Li J, Xue Y, et al. (2004) Parathyroid hormonerelated peptide is required for increased trabecular bone volume in parathyroid hormone-null mice. Endocrinology 145, 3554-3562.

40. Zhang Y, Lai WP, Wu CF, et al. (2007) Ovariectomy worsens secondary hyperparathyroidism in mature rats during low-Ca diet. Am J Physiol Endocrinol Metab 292, E723-E731.

41. Naveh-Many T, Raue F, Grauer A, et al. (1992) Regulation of calcitonin gene expression by hypocalcemia, hypercalcemia, and vitamin D in the rat. J Bone Miner Res 7, 1233-1237.

42. Ferrari S, Bonjour JP \& Rizzoli R (1998) The vitamin D receptor gene and calcium metabolism. Trends Endocrinol Metab 9, 259-265.

43. Tolosa de Talamoni N, Mykkanen H \& Wasserman R (1990) Enhancement of sulfhydryl groups availability in the intestinal brush border membrane by deficiencies of dietary calcium and phosphorus in chicks. J Nutr 120, 1198-1204.
44. Mykkanen HM \& Wasserman RH (1989) Uptake of ${ }^{75} \mathrm{Se}-$ selenite by brush border membrane vesicles from chick duodenum stimulated by vitamin D. J Nutr 119, 242-247.

45. Benn BS, Ajibade D, Porta A, et al. (2008) Active intestinal calcium transport in the absence of transient receptor potential vanilloid type 6 and calbindin- $\mathrm{D}_{9 \mathrm{k}}$. Endocrinology 149, 3196-3205.

46. Kalkwarf HJ, Khoury JC \& Lanphear BP (2003) Milk intake during childhood and adolescence, adult bone density, and osteoporotic fractures in US women. Am J Clin Nutr 77, $10-11$.

47. Kasukawa Y, Baylink DJ, Wergedal JE, et al. (2003) Lack of insulin-like growth factor I exaggerates the effect of calcium deficiency on bone accretion in mice. Endocrinology 144, 4682-4689.

48. Steiner PD, Forrer R, Kneissel M, et al. (2001) Influence of a low calcium and phosphorus diet on the anabolic effect of human parathyroid hormone (1-38) in female rats. Bone 29, 344-351.

49. Zheng Y, Zhou H, Modzelewski JR, et al. (2007) Accelerated bone resorption, due to dietary calcium deficiency, promotes breast cancer tumor growth in bone. Cancer Res 67, 9542-9548.

50. Bezerra FF, Mendonça LM, Lobato EC, et al. (2004) Bone mass is recovered from lactation to postweaning in adolescent mothers with low calcium intakes. Am J Clin Nutr 80, 1322-1326.

51. Bezerra FF, Cabello GM, Mendonça LM, et al. (2008) Bone mass and breast milk calcium concentration are associated with vitamin D receptor gene polymorphisms in adolescent mothers. J Nutr 138, 277-281.

52. North American Menopause Society (2006) The role of calcium in peri- and postmenopausal women: 2006 position statement of the North American Menopause Society. Menopause 13, 862-877.

53. Papaioannou A, Kennedy CC, Ioannidis G, et al. (2009) The impact of incident fractures on health-related quality of life: 5 years of data from the Canadian Multicentre Osteoporosis Study. Osteoporos Int 20, 703-714.

54. Mavroeidi A, Stewart AD, Reid DM, et al. (2009) Physical activity and dietary calcium interactions in bone mass in Scottish postmenopausal women. Osteoporos Int $\mathbf{2 0}$, 409-416.

55. Murayama A, Takeyama K, Kitanaka S, et al. (1999) Positive and negative regulations of the renal 25hydroxyvitamin $\mathrm{D}_{3} 1 \alpha$-hydroxylase gene by parathyroid hormone, calcitonin, and $1 \alpha, 25(\mathrm{OH})_{2} \mathrm{D}_{3}$ in intact animals. Endocrinology 140, 2224-2231.

56. Omdahl JL, Morris HA \& May BK (2002) Hydroxylase enzymes of the vitamin D pathway: expression, function, and regulation. Annu Rev Nutr 22, 139-166.

57. Anderson PH, O'Loughlin PD, May BK, et al. (2003) Quantification of mRNA for the vitamin D metabolizing enzymes CYP27B1 and CYP24 and vitamin D receptor in kidney using real-time reverse transcriptase-polymerase chain reaction. J Mol Endocrinol 31, 123-132.

58. Kato S, Takeyama K, Kitanaka S, et al. (1999) In vivo function of VDR in gene expression-VDR knock-out mice. J Steroid Biochem Mol Biol 69, 247-251.

59. Bajwa A, Horst RL \& Beckman MJ (2005) Gene profiling the effects of calcium deficiency versus 1,25-dihydroxyvitamin D induced hypercalcemia in rat kidney cortex. Arch Biochem Biophys 438, 182-194.

60. Pizzato AC \& Barros EJ (2003) Dietary calcium intake among patients with urinary calculi. Nutr Res $\mathbf{2 3}$ $1651-1660$. 
61. Pasch A, Frey FJ, Eisenberger U, et al. (2008) PTH and 1.25 vitamin $\mathrm{D}$ response to a low-calcium diet is associated with bone mineral density in renal stone formers. Nephrol Dial Transplant 23, 2563-2570.

62. MacDonald HB (2008) Dairy nutrition: what we knew then to what we know now. Int Dairy J 18, 774-777.

63. Zemel MB (2005) The role of dairy foods in weight management. $J$ Am Coll Nutr 24, 537S-546S.

64. Mirmiran P, Azadbakht L \& Azizi F (2005) Dietary qualityadherence to the dietary guidelines in Tehranian adolescents: Tehran Lipid and Glucose Study. Int J Vitam Nutr Res 75, 195-200.

65. Jones BH, Kim JH, Zemel MB, et al. (1996) Upregulation of adipocyte metabolism by agouti protein: possible paracrine actions in yellow mouse obesity. Am J Physiol 270, E192-E196.

66. Xue B, Moustaid N, Wilkison WO, et al. (1998) The agouti gene product inhibits lipolysis in human adipocytes via a $\mathrm{Ca}^{2+}$-dependent mechanism. FASEB J 12, 1391-1396.

67. Zemel MB, Shi H, Greer B, et al. (2000) Regulation of adiposity by dietary calcium. FASEB $J \mathbf{1 4}, 1132-1138$.

68. Major GC, Chaput JP, Ledoux M, et al. (2008) Recent developments in calcium-related obesity research. Obes Rev 9, 428-445.

69. Fujita T \& Palmieri GM (2000) Calcium paradox disease: calcium deficiency prompting secondary hyperparathyroidism and cellular calcium overload. J Bone Miner Metab 18, $109-125$.

70. Xue B, Greenberg AG, Kraemer FB, et al. (2001) Mechanism of intracellular calcium $\left(\left[\mathrm{Ca}^{2+}\right] \mathrm{i}\right)$ inhibition of lipolysis in human adipocytes. FASEB J 15, 2527-2529.

71. Lambert JR, Young CD, Persons KS, et al. (2007) Mechanistic and pharmacodynamic studies of a 25hydroxyvitamin $\mathrm{D}_{3}$ derivative in prostate cancer cells. Biochem Biophys Res Commun 361, 189-195.

72. Tolosa de Talamoni N, Narvaez CJ \& Welsh JE (2004) Menadione potentiates the oxidative stress produced by $1,25(\mathrm{OH})_{2} \mathrm{D}_{3}$ on breast cancer cells. In Proceedings of the XII Biennial Meeting of the Society for Free Radical Research International, Buenos Aires, Argentina, pp. 201-205 [S Puntarulo and A Boveris, editors]. Bologna, Italy: Medimond.

73. Sun X \& Zemel MB (2004) Calcium and dairy products inhibit weight and fat regain during ad libitum consumption following energy restriction in Ap2-agouti transgenic mice. J Nutr 134, 3054-3060.

74. Prins JB, Walker NI, Winterford CM, et al. (1994) Human adipocyte apoptosis occurs in malignancy. Biochem Biophys Res Commun 205, 625-630.

75. Della-Fera MA, Qian H \& Baile CA (2001) Adipocyte apoptosis in the regulation of body fat mass by leptin. Diabetes Obes Metab 3, 299-310.

76. Morris KL \& Zemel MB (2005) 1,25-Dihydroxyvitamin $\mathrm{D}_{3}$ modulation of adipocyte glucocorticoid function. Obes Res 13, 670-677.

77. Loos RJ, Rankinen T, Leon AS, et al. (2004) Calcium intake is associated with adiposity in black and white men and white women of the HERITAGE Family Study. J Nutr 134, $1772-1778$.

78. Jackmain M, Doucet E, Despres J, et al. (2003) Calcium intake, body composition and lipoprotein-lipid concentrations in adults. Am J Clin Nutr 77, 1448-1452.

79. Barr S (2003) Increased dairy product or calcium intake: is body weight or composition affected in humans? J Nutr 133, 245S-248S.
80. Heiss CJ, Shaw SE \& Carothers L (2008) Association of calcium intake and adiposity in postmenopausal women. $J$ Am Coll Nutr 27, 260-266.

81. Addison WLT \& Clark HG (1924) Calcium and potassium chlorides in the treatment of arterial hypertension. Can Med Assoc J 15, 913-915.

82. Crawford MD, Gardner MJ \& Morris JN (1968) Mortality and hardness of local water supplies. Lancet 20, 827-831.

83. McCarron DA, Morris CD \& Cole C (1982) Dietary calcium in human hypertension. Science 217, 267-269.

84. McCarron DA, Morris CD \& Stanton JL (1984) Hypertension and calcium. Science 226, 386-393.

85. Bucher HC, Guyatt GH, Cook RJ, et al. (1996) Effect of calcium suplementation on pregnancy-induced hypertension and preeclampsia: a meta-analysis of randomized controlled trials. JAMA 275, 1113-1117.

86. Griffith LE, Guyatt GH, Cook RJ, et al. (1999) The influence of dietary and nondietary calcium supplementation on blood pressure: an updated metaanalysis of randomized controlled trials. Am J Hypertens 12, 84-92.

87. Resnick LM (1999) The role of dietary calcium in hypertension: a hierarchical overview. Am J Hypertens 12, 99-112.

88. Zemel MB (1994) Dietary calcium, calcitrophic hormones and hypertension. Nutr Metab Cardiovasc Dis 4, 224-228.

89. Appel LJ, Moore TJ, Obarzanek E, et al. (1997) A clinical trial of the effects of dietary patterns on blood pressure. DASH Collaborative Research Group. N Engl J Med 336, 1117-1124.

90. Wang L, Manson JE, Buring JE, et al. (2008) Dietary intake of dairy products, calcium, and vitamin $\mathrm{D}$ and the risk of hypertension in middle-aged and older women. Hypertension 51, 1073-1079.

91. Alonso A, Beunza JJ, Delgado-Rodríguez M, et al. (2005) Low-fat dairy consumption and reduced risk of hypertension: the Seguimiento Universidad de Navarra (SUN) cohort. Am J Clin Nutr 82, 972-979.

92. Vyas HK \& Tong PS (2003) Process for calcium retention during skim milk ultrafiltration. J Dairy Sci 86, 2761-2766.

93. FitzGerald RJ, Murray BA \& Walsh DJ (2004) Hypotensive peptides from milk proteins. J Nutr 134, 980S-988S.

94. Weiss D \& Taylor WR (2008) Deoxycorticosterone acetate salt hypertension in apolipoprotein $\mathrm{E}^{-1-}$ mice results in accelerated atherosclerosis: the role of angiotensin II. Hypertension 51, 218-224.

95. Ramón de Berrazueta J (1999) The role of calcium in the regulation of normal vascular tone and in arterial hypertension. Rev Esp Cardiol 52, 25-33.

96. Scholz-Ahrens KE \& Schrezenmeir J (2006) Milk minerals and the metabolic syndrome. Int Dairy J 16, 1399-1407.

97. Szollosi A, Nenquin M, Aguilar-Bryan L, et al. (2006) Glucose stimulates $\mathrm{Ca}^{2+}$ influx and insulin secretion in 2-week-old $\beta$-cells lacking ATP-sensitive $\mathrm{K}^{+}$channels. J Biol Chem 282, 1747-1756.

98. Myers VH \& Champagne CM (2007) Nutritional effects on blood pressure. Curr Opin Lipidol 18, 20-24.

99. Ryan-Harshman M \& Aldoori W (2007) Diet and colorectal cancer: review of the evidence. Can Fam Physician 53, 1913-1920.

100. Holt PR, Atillasoy EO, Gilman J, et al. (1998) Modulation of abnormal colonic epithelial cell proliferation and differentiation by low-fat dairy foods: a randomized controlled trial. JAMA 280, 1074-1079.

101. McCullough ML, Robertson AS, Rodriguez C, et al. (2003) Calcium, vitamin D, dairy products, and risk of colorectal cancer in the Cancer Prevention Study II Nutrition Cohort (United States). Cancer Causes Control 14, 1-12. 
102. Terry P, Baron JA, Bergkvist L, et al. (2002) Dietary calcium and vitamin D intake and risk of colorectal cancer: a prospective cohort study in women. Nutr Cancer 43, 39-46.

103. Pietinen P, Malila N, Virtanen M, et al. (1999) Diet and risk of colorectal cancer in a cohort of Finnish men. Cancer Causes Control 10, 387-396.

104. Järvinen R, Knekt P, Hakulinen T, et al. (2001) Prospective study on milk products, calcium and cancers of the colon and rectum. Eur J Clin Nutr 55, 1000-1007.

105. Hofstad B, Almendingen K, Vatn M, et al. (1998) Growth and recurrence of colorectal polyps: a double-blind 3-year intervention with calcium and antioxidants. Digestion 59, $148-156$

106. Grau MV, Baron JA, Sandler RS, et al. (2003) Vitamin D, calcium supplementation, and colorectal adenomas: results of a randomized trial. J Natl Cancer Inst 95, 1765-1771.

107. Marcus PM \& Newcomb PA (1998) The association of calcium and vitamin $\mathrm{D}$, and colon and rectal cancer in Wisconsin women. Int J Epidemiol 27, 788-793.

108. Franceschi S \& Favero A (1999) The role of energy and fat in cancers of the breast and colon-rectum in a southern European population. Ann Oncol 6, 61-63.

109. Levi F, Pasche C, Lucchini F, et al. (2000) Selected micronutrients and colorectal cancer. a case-control study from the canton of Vaud, Switzerland. Eur J Cancer 36, 2115-2119

110. Pritchard RS, Baron JA \& Gerhardsson de Verdier M (1996) Dietary calcium, vitamin D, and the risk of colorectal cancer in Stockholm, Sweden. Cancer Epidemiol Biomarkers Prev 5, 897-900.

111. Cho E, Smith-Warner SA, Spiegelman D, et al. (2004) Dairy foods, calcium, and colorectal cancer: a pooled analysis of 10 cohort studies. J Natl Cancer Inst 96, 1015-1022.

112. Park SY, Murphy SP, Wilkens LR, et al. (2007) Calcium and vitamin D intake and risk of colorectal cancer: the Multiethnic Cohort Study. Am J Epidemiol 165, 784-793.

113. Wallace K, Baron JA, Cole BF, et al. (2004) Effect of calcium supplementation on the risk of large bowel polyps. J Natl Cancer Inst 96, 921-925.

114. Shaukat A, Scouras N \& Schünemann HJ (2005) Role of supplemental calcium in the recurrence of colorectal adenomas: a metaanalysis of randomized controlled trials. Am J Gastroenterol 100, 390-394.

115. Bises G, Bajna E, Manhardt T, et al. (2007) Gender-specific modulation of markers for premalignancy by nutritional soy and calcium in the mouse colon. J Nutr 137, 211S-215S.

116. Pele LC, Thoree V, Mustafa F, et al. (2007) Low dietary calcium levels modulate mucosal caspase expression and increase disease activity in mice with dextran sulfate sodium induced colitis. J Nutr 137, 2475-2480.

117. Hobson SA, Wright J, Lee F, et al. (2003) Activation of the MAP kinase cascade by exogenous calcium-sensing receptor. Mol Cell Endocrinol 200, 189-198.

118. Chakrabarty S, Radjendirane V, Appelman H, et al. (2003) Extracellular calcium and calcium sensing receptor function in human colon carcinomas: promotion of E-cadherin expression and suppression of $\beta$-catenin/TCF activation. Cancer Res 63, 67-71.
119. Farrow DC \& Davis S (1990) Diet and the risk of pancreatic cancer in men. Am J Epidemiol 132, 423-431.

120. Kemmis CM \& Welsh J (2008) Mammary epithelial cell transformation is associated with deregulation of the vitamin D pathway. J Cell Biochem 105, 980-988.

121. Mordan-McCombs S, Brown T, Zinser G, et al. (2007) Dietary calcium does not affect prostate tumor progression in LPB-Tag transgenic mice. J Steroid Biochem Mol Biol 103, 747-751.

122. Baron JA, Beach M, Wallace K, et al. (2005) Risk of prostate cancer in a randomized clinical trial of calcium supplementation. Cancer Epidemiol Biomarkers Prev 14, 586-589.

123. Torniainen S, Hedelin M, Autio V, et al. (2007) Lactase persistence, dietary intake of milk, and the risk for prostate cancer in Sweden and Finland. Cancer Epidemiol Biomarkers Prev 16, 956-961.

124. Bonjour JP, Chevalley T \& Fardellone P (2007) Calcium intake and vitamin D metabolism and action, in healthy conditions and in prostate cancer. Br J Nutr 97, 611-616.

125. Xue L, Yang K, Newmark H, et al. (1996) Epithelial cell hyperproliferation induced in the exocrine pancreas of mice by a Western-style diet. J Natl Cancer Inst 88, 1586-1590.

126. Skinner HG, Michaud DS, Giovannucci E, et al. (2006) Vitamin D intake and the risk for pancreatic cancer in two cohort studies. Cancer Epidemiol Biomarkers Prev 15, $1688-1695$

127. Stolzenberg-Solomon RZ, Vieth R, Azad A, et al. (2006) A prospective nested case-control study of vitamin D status and pancreatic cancer risk in male smokers. Cancer Res $\mathbf{6 6}$, 10213-10219.

128. Stolzenberg-Solomon RZ, Hayes RB, Horst RL, et al. (2009) Serum vitamin D and risk of pancreatic cancer in the prostate, lung, colorectal, and ovarian screening trial. Cancer Res 69, 1439-1447.

129. Cramer DW (1989) Lactase persistence and milk consumption as determinants of ovarian cancer risk. Am J Epidemiol 130, 904-910.

130. Goodman MT, Wu AH, Tung KH, et al. (2002) Association of dairy products, lactose, and calcium with the risk of ovarian cancer. Am J Epidemiol 156, 148-157.

131. Kuokkanen M, Butzow R, Rasinperä H, et al. (2005) Lactase persistence and ovarian carcinoma risk in Finland, Poland and Sweden. Int J Cancer 117, 90-94.

132. Fung WL, Risch H, McLaughlin J, et al. (2003) The N314D polymorphism of galactose-1-phosphate uridyl transferase does not modify the risk of ovarian cancer. Cancer Epidemiol Biomarkers Prev 12, 678-680.

133. Qin LQ, Xu JY, Wang PY, et al. (2005) Milk/dairy products consumption, galactose metabolism and ovarian cancer: meta-analysis of epidemiological studies. Eur $J$ Cancer Prev 14, 13-19.

134. Mommers M, Schouten LJ, Goldbohm RA, et al. (2006) Dairy consumption and ovarian cancer risk in The Netherlands Cohort Study on Diet and Cancer. Br J Cancer 94, 165-170.

135. Genkinger JM, Hunter DJ, Spiegelman D, et al. (2006) Dairy products and ovarian cancer: a pooled analysis of 12 cohort studies. Cancer Epidemiol Biomarkers Prev 15, $364-372$. 